Article

\title{
Developing a Green Building Index (GBI) Certification System to Effectively Reduce Carbon Emissions in South Korea's Building Industry
}

\author{
Seungjun Roh ${ }^{1}$ (D), Sungho Tae ${ }^{1,2, *}$ and Rakhyun Kim ${ }^{3, *}$ \\ 1 Sustainable Building Research Center, Hanyang University, 55 Hanyangdaehak-ro, Sangnok-gu, \\ Ansan 15588, Korea; roh.seungjun@gmail.com \\ 2 Department of Architecture \& Architectural Engineering, Hanyang University, 55 Hanyangdaehak-ro, \\ Sangnok-gu, Ansan 15588, Korea \\ 3 Architectural Engineering, Hanyang University, 55 Hanyangdaehak-ro, Sangnok-gu, Ansan 15588, Korea \\ * Correspondence: jnb55@hanyang.ac.kr (S.T.); redwow6@hanyang.ac.kr (R.K.); \\ Tel.: +82-31-400-5187 (S.T.); +82-31-436-8076 (R.K.)
}

Received: 7 April 2018; Accepted: 29 May 2018; Published: 4 June 2018

\begin{abstract}
The building industry is currently strengthening the building life cycle assessment (LCA) criteria of the green building certification system to encourage carbon emission reduction. However, the voluntary approach of the LCA criteria does not provide sufficient incentive to effectively drive green building construction. Furthermore, additional costs associated with green building construction are not given enough weightage, thus hampering the incorporation of green building technologies. This study developed a Green Building Index (GBI) Certification System to effectively reduce carbon emissions in South Korea's building industry. Consequently, the assessment areas for green buildings were divided into a carbon emission index, a building habitability index, and a carbon economic index, and assessment methods were suggested for each area. In addition, eco-efficiency, which represents an environmental value, was incorporated into the three indices from the perspective of green building certification and used to estimate a GBI that represents overall building sustainability. This GBI was then integrated into an overall GBI Certification System, and a case study was used to evaluate its applicability. The results indicate the validity of the proposed GBI Certification System, which promotes voluntary carbon emission reduction by evaluating cost effectiveness based on life cycle carbon emissions and carbon economic efficiency.
\end{abstract}

Keywords: green building index; green building certification system; carbon emission; triple bottom line; eco-efficiency

\section{Introduction}

Dramatic population growth and rapid, technology-based industrial development that began at the end of the 20th century have resulted in a host of international environmental issues, global warming being at the forefront [1,2]. As a result, industries are employing a variety of strategies to reduce carbon emissions, one of the main drivers of global warming [3-5]. In particular, the building industry, which is reportedly responsible for more than $32 \%$ of global carbon emissions [6-8], is encouraging green building construction, which reduces carbon emissions, creates economic profits, and increases the occupancy's amenity and health by reducing building material quantities and operational energy consumption $[9,10]$. As part of a strategy designed to encourage green building construction, the building industry is currently in the process of strengthening the certification criteria for building life cycle assessment (LCA) in conjunction with the development of a green building certification system [11-17]. The building LCA criteria quantitatively evaluate potential 
carbon emissions and other environmental impacts during a building's entire life cycle [17-20]. Similar frameworks have been developed in other countries, including the Leadership in Energy and Environmental Design (LEED), a green building certification system in the U.S., and the Building Research Establishment Environmental Assessment Method (BREEAM). A green building certification system in the U.K. These systems continually strengthen building LCA criteria by revising green building criteria, changing the LCA from an optional item to a core consideration [21-26].

Following these international movements, South Korea developed the Green Standard for Energy and Environmental Design (G-SEED), a green building certification system that incorporates building LCA as a merit item in G-SEED 2016 [27]. Through G-SEED, real estate developers and builders in South Korea are being encouraged to reduce carbon emissions. However, for G-SEED to evolve into an effective certification system for reducing building carbon emissions, four criteria must be improved.

- Building LCA criteria are currently listed as a merit item and are not enforced as a mandatory item. While the inclusion of building LCA criteria in G-SEED 2016 is promising, many building projects neglect or avoid the consideration of building LCA criteria due to the burden of additional costs and labor associated with the preparation of certain documents, such as design statements or construction statements, and building energy efficiency rating certification that is required to earn the G-SEED preliminary certification or certification for a building LCA.

- Standards for life cycle carbon emissions of a reference building must be provided to confirm a reduction in carbon emissions with LCA results. The current G-SEED certification criteria for a building LCA quantitatively evaluate environmental impacts of carbon emissions and more according to the building LCA guideline. Thereafter, a maximum of two points worth of the certification score are earned once a third-party examiner confirms the suitability of the assessment results [27]. This system is considered to be very convenient in the early stages of implementing building LCA criteria. However, it is limited in that the degree of environmental impact including carbon emissions is not reflected in the certification scores. Meanwhile, LEED in the U.S. grants certification scores only when the environmental impact is reduced by $10 \%$ or higher compared to a reference building [25].

- Additional costs incurred in green building construction that reduces carbon emissions, and actual economic benefits acquired from operating the green building, are not reflected in the certification ratings. Currently, certification criteria that evaluate life cycle costs of buildings are not part of G-SEED, and thus, an integral assessment of improved ecofriendly performance and carbon emission reduction effects due to additional invested costs in the early stages of a construction project are not possible. Moreover, despite building owners receiving actual economic benefits from carbon emission reduction and energy cost reduction from constructing green buildings, the percentage of scores given for the energy savings element is limited to $62 \%$.

- The simple weighted summation method used by G-SEED for certification rating calculations is inadequate, and a relative efficiency index in terms of carbon emission reduction would provide a more comprehensive assessment and valuation of green building design. The simple weighted summation method is relatively practical for obtaining scores since the certification rating is based on the total earned score. However, the scores concentrate too much on certification criteria concerning less cost. The average certification score of G-SEED for apartment buildings is approximately 72 points, which is an excellent rating. However, the certification score percentages for assessment sub-categories such as water resources, air pollution, and the ecological environment, which effectively promote carbon emission reduction, remain at $50 \%$. This shows that the primary decision-making process is focused on business aspects (early construction cost) instead of aspects that facilitate a reduction in carbon emissions. For these reasons, researchers have noted the irony that certain buildings with a higher certification rating may actually consume more energy and produce more carbon emissions than buildings with a lower certification rating [28-31]. 
The purpose of this study was to develop a Green Building Index (GBI) Certification System for reducing carbon emissions for South Korea's building industry, by improving upon the four types of problems listed above. Notably, the GBI Certification System developed in this study is more quantitative than G-SEED, as it promotes voluntary carbon emission reduction by evaluating cost effectiveness, and it will ultimately contribute to the reduction of carbon emissions in new building construction in South Korea.

\section{Green Building Index (GBI) Certification System}

This study proposes the development of a GBI Certification System via a thorough evaluation of a building's sustainability by applying the concepts of Triple Bottom Line (TBL) and eco-efficiency. As Figure 1 shows, the TBL is a popular accounting framework that incorporates three dimensions of sustainability, namely, environmental, social, and economic [32-36]. Eco-efficiency, a concept developed and promoted by the World Business Council for Sustainable Development (WBCSD), expresses the relationship between a product's (or service's) value and its environmental impact with an efficiency index (i.e., product value $\div$ environmental impact) [37].

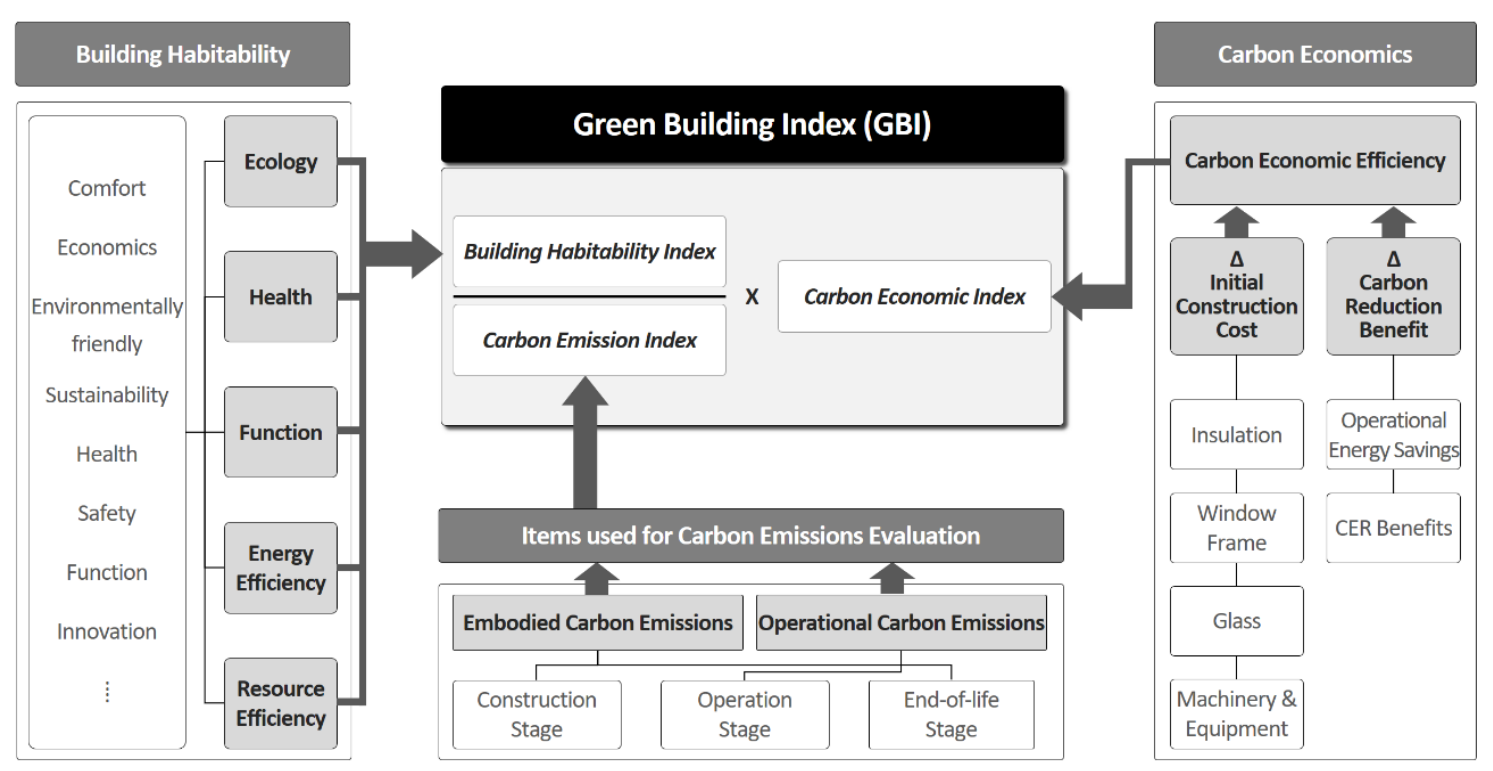

Figure 1. Concept and evaluation framework of GBI.

Thus, GBI expresses environmental, social, and economic performance of a building project via a carbon emission index, building habitability index, and carbon economic index [38]. A simplified expression of the overall relationship among these three indices is presented as Equation (1). In other words, GBI evaluates building life cycle carbon emissions from an environmental aspect and building habitability from a social aspect. The goal is to study the relative efficiency of building habitability per unit carbon emission and to evaluate the effectiveness of increased costs entailed for reducing carbon emissions from an economic aspect, so as to assign appropriate weightage to these elements.

This GBI can be used to address the four primary issues discussed in Section 1. Building LCA can be required in the G-SEED certification process since the carbon emission index is necessary for calculating GBI, as seen in Equation (1). The carbon emission assessment results of an evaluated building can be reflected in the certification score since building life cycle carbon emissions of a reference building are included as a variable in Equation (2) in the calculation process for the carbon emission index. Additional costs invested in the early stages of construction projects and actual economic benefits from green building operation can be reflected in certification ratings since the carbon economic index is required for GBI calculation. Since the GBI is a relative efficiency index 
comprising of indices that represent the environmental, social, and economic aspects of a building, a green building certification system can evaluate the sustainability of a well-balanced building and reflect the results in the certification ratings.

$$
\mathrm{GBI}=\frac{\mathrm{Q}}{\mathrm{C}} \times \mathrm{E}
$$

where GBI is the green building index $(1.2 \leqq \mathrm{GBI} \leqq 5)$, $\mathrm{Q}$ is the building habitability index, $\mathrm{C}$ is the carbon emission index, and $\mathrm{E}$ is the carbon economic index.

\subsection{Carbon Emission Index}

Figure 2 presents the assessment range for building life cycle carbon emissions. The carbon emission index is a relative efficiency ratio between an evaluated building and a reference building in terms of embodied carbon emissions and operational carbon emissions, as shown in Equation (2). The embodied carbon emissions refer to the total of carbon emissions arising from the construction material production, construction material transportation, building construction, building maintenance, building dissolution, waste transportation, incineration, and landfill processes [39-46], as shown in Equation (3). On the other hand, the operational emissions refer to carbon emissions that arise from energy consumed by the operational stages during the service life of a building, as shown in Equation (4).

$$
\begin{gathered}
C=\alpha \times \frac{E C_{E}}{E C_{R}}+\beta \times \frac{O C_{E}}{O C_{R}} . \\
E_{i}=P_{i}+T_{i}+C_{i}+M_{i}+D_{i}+W_{i}+I_{i}+L_{i} \\
O C_{i}=Q_{i} \times S L
\end{gathered}
$$

where $\mathrm{C}$ is the carbon emission index; $\mathrm{EC}_{\mathrm{E}}$ and $\mathrm{EC}_{\mathrm{R}}$ are the carbon emissions of the evaluated building and reference building, respectively; $\mathrm{OC}_{\mathrm{E}}$ and $\mathrm{OC}_{\mathrm{R}}$ are the operational carbon emissions of the evaluated building and reference building, respectively; and $\alpha$ and $\beta$ are weights for each area. $\alpha$ and $\beta$ were both set to 0.125 to adjust the range of GBI $(1.2 \leqq \mathrm{GBI} \leqq 5) . \mathrm{EC}_{\mathrm{i}}$ represents the embodied carbon emissions of building (i), and $\mathrm{P}_{\mathrm{i}}, \mathrm{T}_{\mathrm{i}}, \mathrm{C}_{\mathrm{i}}, \mathrm{M}_{\mathrm{i}}, \mathrm{D}_{\mathrm{i}}, \mathrm{W}_{\mathrm{i}}, \mathrm{I}_{\mathrm{i}}$, and $\mathrm{L}_{\mathrm{i}}$ each represent carbon emissions from the construction material production, construction material transportation, building construction, building maintenance, building dissolution, waste transportation, incineration, and landfill processes for building (i), respectively. $O C_{i}$ represents the operational carbon emissions of building (i), $O C_{i}$ is the annual operational carbon emissions of building (i), and SL is the service life of the building.

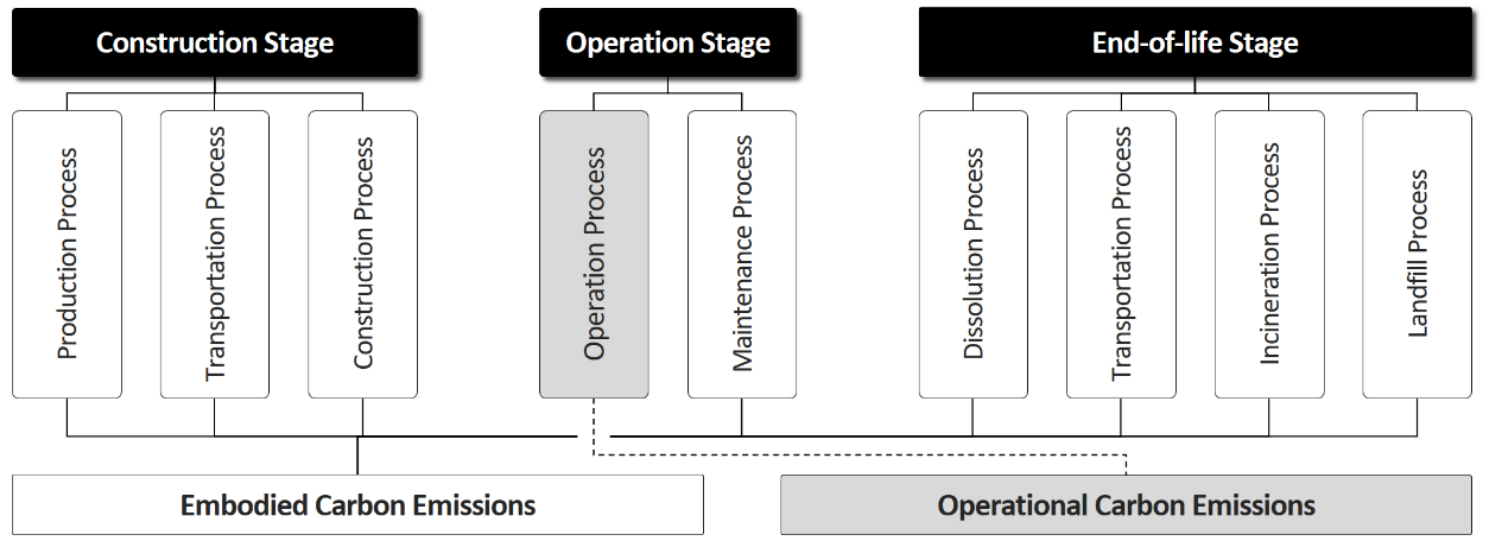

Figure 2. Assessment range for building life cycle carbon emissions.

It is important to note that assessing carbon emissions for all construction materials used in a building accordingly in the G-SEED certification process is difficult since more than 1000 different 
construction materials are typically used in the construction of a new building. Therefore, this study applied a streamlined LCA approach, which considered primary construction materials with high carbon emissions among all the materials used in a building, and analyzed the life cycle scenarios of these construction materials. Table 1 shows the main construction materials and the life cycle scenario for each main material considered in this study.

Table 1. Life cycle scenarios for the main construction materials considered in this study.

\begin{tabular}{|c|c|c|c|c|c|c|c|}
\hline \multicolumn{2}{|c|}{ Classification } & $\begin{array}{l}\text { Ready-Mixed } \\
\text { Concrete }\end{array}$ & Rebar & Glass & $\begin{array}{c}\text { Concrete } \\
\text { Brick }\end{array}$ & Insulation & Plaster Board \\
\hline \multirow{3}{*}{ Construction Stage } & Production Process & \multicolumn{6}{|c|}{ Carbon emission based on LCI DB according to the quantity of construction materials } \\
\hline & Transportation Process & $\begin{array}{l}\text { Truck mixer } \\
\text { (TD: } 30 \mathrm{~km} \text { ) }\end{array}$ & $\begin{array}{l}20 \text { ton truck } \\
\text { (TD: } 30 \mathrm{~km} \text { ) }\end{array}$ & $\begin{array}{c}8 \text { ton truck } \\
(30 \mathrm{~km})\end{array}$ & $\begin{array}{c}8 \text { ton truck } \\
(30 \mathrm{~km})\end{array}$ & $\begin{array}{c}8 \text { ton truck } \\
(30 \mathrm{~km})\end{array}$ & $\begin{array}{c}8 \text { ton truck } \\
(30 \mathrm{~km})\end{array}$ \\
\hline & Construction Process & \multicolumn{6}{|c|}{ Carbon emission based on LCI DB according to the basic activity } \\
\hline Operation Stage & Operation Process & \multicolumn{6}{|c|}{ Carbon Emission based on building energy efficiency rating certification (Service life: 40 years) } \\
\hline \multirow{4}{*}{ End-of-life Stage } & Dissolution Process & \multicolumn{6}{|c|}{ Carbon emission based on mileage of dissolution equipment } \\
\hline & Transportation Process & $\begin{array}{l}15 \text { ton truck } \\
\text { (TD: } 30 \mathrm{~km})\end{array}$ & $\begin{array}{l}15 \text { ton truck } \\
\text { (TD: } 30 \mathrm{~km})\end{array}$ & $\begin{array}{l}15 \text { ton truck } \\
\text { (TD: } 30 \mathrm{~km})\end{array}$ & $\begin{array}{l}15 \text { ton truck } \\
\text { (TD: } 30 \mathrm{~km} \text { ) }\end{array}$ & $\begin{array}{l}15 \text { ton truck } \\
\text { (TD: } 30 \mathrm{~km})\end{array}$ & $\begin{array}{l}15 \text { ton truck } \\
\text { (TD: } 30 \mathrm{~km})\end{array}$ \\
\hline & Incineration Process & IR: $0.0 \%$ & IR: $0.0 \%$ & IR: $0.0 \%$ & IR: $0.0 \%$ & IR: $53.3 \%$ & IR: $0.2 \%$ \\
\hline & Landfill Process & LR: $0.0 \%$ & LR: $0.0 \%$ & LR: $21.0 \%$ & LR: $0.0 \%$ & LR: $0.0 \%$ & LR: $37.1 \%$ \\
\hline
\end{tabular}

TD: Transportation Distance, RP: Repair Period, RR: Repair Rate, IR: Incineration Rate, LR: Landfill Rate.

Six construction materials identified in a previous study $[47,48]$ according to the LCA cut-off criteria of ISO 14040 [49] were selected as the primary construction materials. These construction materials include ready-mixed concrete, rebar, glass, concrete brick, insulation, and plaster board, and are responsible for more than $95 \%$ of carbon emissions from construction materials used in buildings in South Korea. For construction material transportation, vehicles typically used for each construction material were selected based on the national standard estimation system relevant to construction work [50], and the transportation distance was set to $30 \mathrm{~km}$. The LCI DB (Life Cycle Inventory Database) established according to the work units of primary construction materials was applied to describe and define the building construction process [51].

Calculations of the building's operational carbon emissions were based on general operational assumptions and a building energy efficiency rating certification (the submission of which is mandatory in South Korea to obtain a license), and a construction commencement report. The building's service life was assumed to be 40 years for the purposes of the calculation. Repair periods and repair rates for different construction materials for the building maintenance process were sourced from the Housing Act in Korea [52].

For the building demolition process, carbon emissions from equipment demolishing the construction material were calculated. For waste transportation, a 15-ton truck was selected as the transportation vehicle and $30 \mathrm{~km}$ was set as the transportation distance based on the national standard estimation system regarding construction work [50]. The recycle, incineration, and landfill rates for construction waste were provided by the Korea Environmental Industry \& Technology Institute [53]. These rates are based on the current state of waste generation and processing throughout the country and were used for estimating the carbon emissions associated with the incineration and landfill processes.

\subsection{Building Habitability Index}

The building habitability index helps assess building performance according to specific areas that constitute building habitability. It is similar to the indexes in the green building assessment systems [54-56] of different countries, such as LEED in the U.S. [25], BREEAM in the U.K. [26], and G-SEED in South Korea [27]. This study divided specific aspects influencing building habitability into five core characteristics: ecology, health, function, energy efficiency, and resource efficiency (as shown in Figure 3). A total of 49 assessment sub-criteria were considered, as shown in Table 2. Habitability of 
an evaluated building can be assessed through an evaluation of these sub-criteria, and the building habitability index is calculated using Equation (5).

$$
\mathrm{Q}=\sum_{\mathrm{i}=1}^{5}\left(\frac{\mathrm{S}_{\mathrm{i}} \times \mathrm{W}_{\mathrm{i}}}{\mathrm{DM}_{\mathrm{i}}}\right) \times \frac{1}{100} .
$$

where $\mathrm{Q}$ represents the building habitability index, $\mathrm{S}_{\mathrm{i}}$ represents the score obtained by the evaluated building in specific area (i), and $\mathrm{DM}_{\mathrm{i}}$ and $\mathrm{W}_{\mathrm{i}}$ each represent allotted scores and weights for assessing carbon emissions from that specific area (i).

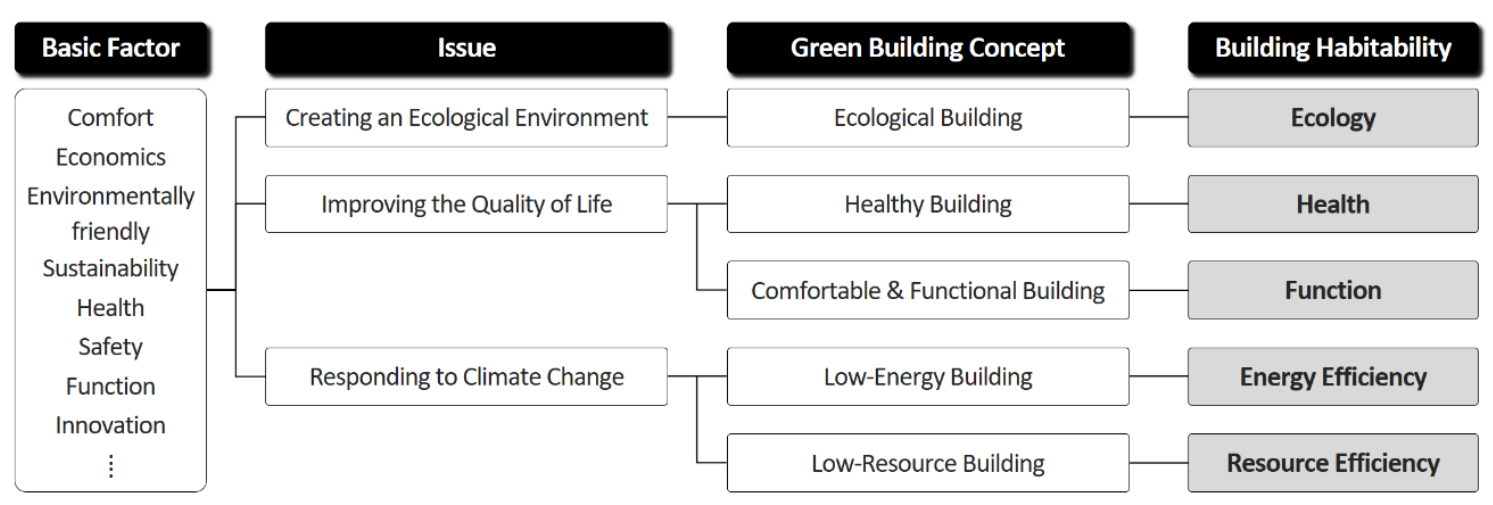

Figure 3. Aspects affecting building habitability.

\subsection{Carbon Economic Index}

Carbon economic efficiency can be expressed as the ratio of construction costs for reducing a building's life cycle carbon emissions to the benefit associated with carbon emission reduction during the service life of the building. It includes carbon emission trading, as shown in Equation (6). Construction costs for an evaluated building refer to costs of incorporating green building technology into insulation, window frames, glass, and machine equipment (including new and renewable energy systems), ultimately increasing the operating energy efficiency. The construction cost for a reference building refers to costs for simple insulation, windows and doors, and machine equipment, but no added costs for green building technology. Carbon economic efficiency has a structure similar to that of tax increment financing projects, a conventional green building financing method often used for energy service company (ESCO) projects $[57,58]$. However, carbon economic efficiency considers not only energy reduction benefits during the service life of the building (which is considered by conventional projects), but also carbon emission trading profits resulting from carbon emission reduction.

$$
\mathrm{CE}=\frac{\Delta \mathrm{RB}}{\Delta \mathrm{IC}} \times 100=\left(\frac{\mathrm{OE}_{\mathrm{R}}-\mathrm{OE}_{\mathrm{E}}+\mathrm{CB}}{\mathrm{IC}_{\mathrm{E}}-\mathrm{IC}_{\mathrm{R}}}\right) \times 100
$$

where $\mathrm{CE}$ is carbon economic efficiency $(\%) ; \Delta \mathrm{RB}$ is carbon emission reduction benefit; $\Delta \mathrm{IC}$ is increased construction cost; $\mathrm{OE}_{\mathrm{E}}$ and $\mathrm{OE}_{\mathrm{R}}$ refer to annual operational costs for the evaluated building and reference building, respectively; $\mathrm{IC}_{\mathrm{E}}$ and $\mathrm{IC}_{\mathrm{R}}$ refer to initial construction costs for the evaluated building and reference building, respectively; and $\mathrm{CB}$ is the carbon emission trading profit. 
Table 2. Assessment sub-criteria for building habitability.

\begin{tabular}{|c|c|c|c|c|c|}
\hline Classification & & Assessment Sub-Criteria & & & Weight Factor \\
\hline \multirow{6}{*}{ Ecology } & \multirow{6}{*}{ Ecology } & Provision of a green axis & 2 & \multirow{6}{*}{20} & \multirow{6}{*}{23} \\
\hline & & Ratio of ecological areas & 6 & & \\
\hline & & Provision of biotopes & 4 & & \\
\hline & & Ecology value of sites & 2 & & \\
\hline & & Ratio of natural grounds & 4 & & \\
\hline & & Minimize the soil erosion & 2 & & \\
\hline \multirow{13}{*}{ Health } & \multirow{9}{*}{ Air } & Use of low-VOC-(volatile organic compound)-emitting products & 6 & \multirow{13}{*}{36} & \multirow{13}{*}{22} \\
\hline & & Natural ventilation & 3 & & \\
\hline & & Fungus resistant & 2 & & \\
\hline & & Control and monitoring of indoor $\mathrm{CO}_{2}$ and harmful substance & 2 & & \\
\hline & & Sound insulation between dwellings & 2 & & \\
\hline & & Lightweight and heavyweight floor impact sound insulation & 4 & & \\
\hline & & Toilet water supply/drainage noise & 2 & & \\
\hline & & Provision of daylights & 4 & & \\
\hline & & Limiting the use of ozone-destroying materials & 3 & & \\
\hline & Sound & Traffic (road, railway) noise & 2 & & \\
\hline & \multirow{3}{*}{ Light } & Effects of building direction & 2 & & \\
\hline & & Reduction of light pollution & 2 & & \\
\hline & & Feasibility of the measure to prevent interference with daylight rights & 2 & & \\
\hline \multirow{12}{*}{ Function } & \multirow{7}{*}{$\begin{array}{l}\text { Operation and } \\
\text { Maintenance }\end{array}$} & Reasonableness of site management plan & 1 & \multirow{12}{*}{22} & \multirow{12}{*}{12} \\
\hline & & Provision of manuals/guidelines for the building managers & 2 & & \\
\hline & & TAB and commissioning & 2 & & \\
\hline & & Ease of repair & 2 & & \\
\hline & & Auto-temperature-adjusting device for each room & 2 & & \\
\hline & & Provision of user manuals for the building occupants & 1 & & \\
\hline & & Participation of green building expert & 2 & & \\
\hline & \multirow{5}{*}{ Performance } & Bicycle storage and roads & 2 & & \\
\hline & & Access to amenity & 2 & & \\
\hline & & Installation of alternative transportation & 2 & & \\
\hline & & Access to public transport & 2 & & \\
\hline & & Innovative Design & 2 & & \\
\hline \multirow{7}{*}{$\begin{array}{l}\text { Energy } \\
\text { Efficiency }\end{array}$} & \multirow{7}{*}{ Energy } & Energy Efficiency & 12 & \multirow{7}{*}{24} & \multirow{7}{*}{25} \\
\hline & & Use of new/renewable energy & 3 & & \\
\hline & & Prevent of heat bridge & 2 & & \\
\hline & & Energy monitoring and managing equipment & 2 & & \\
\hline & & High efficiency home appliances & 1 & & \\
\hline & & Heat island effect & 2 & & \\
\hline & & Installation of awning & 2 & & \\
\hline \multirow{12}{*}{$\begin{array}{l}\text { Resource } \\
\text { Efficiency }\end{array}$} & & Use of eco-friendly-certified products & 3 & \multirow{11}{*}{35} & \multirow{11}{*}{18} \\
\hline & & Recycling of reusable resources & 2 & & \\
\hline & & Saving resources and materials by reusing the main structures & 7 & & \\
\hline & Resource & Reducing food waste & 2 & & \\
\hline & & Appropriateness of the measure to reduce the living furniture materials & 3 & & \\
\hline & & Flexibility & 3 & & \\
\hline & & Displaying the carbon emission of materials & 2 & & \\
\hline & & Reduction plan of rainwater & 3 & & \\
\hline & Whater & Reduction plan of water for living & 4 & & \\
\hline & Water & Rainwater harvesting & 3 & & \\
\hline & & Grey-water facilities & 3 & & \\
\hline & & Total & & & 100 \\
\hline
\end{tabular}

Using this CE approach, this study applied a weighted carbon economic index in the calculation of the GBI to increase the overall green value of buildings (refer to Equation (1)). However, this approach can result in a large range of GBI values depending on the carbon economic index used. Consequently, the maximum weighted value of the carbon economic index was limited to $20 \%$, and the range was set as $1-1.2$. This $20 \%$ fluctuation range allows the GBI rating to increase by at least 1 grade or more after the application of a weighted carbon economic index. Moreover, carbon economic 
efficiency is the rate of return on investment (ROI) for green building construction. As a result, a system is required to convert ROI to a carbon economic index. This study set the minimum return rate at $4 \%$ considering that the most current interest rates published by the National Statistical Office were $4 \%$ or lower [59]. The maximum carbon economic efficiency was set to $8 \%$ considering that most interest rates of project financing structures based on business value were $8-10 \%$ [59]. Thus, when the ROI of green buildings was lower than $4 \%$, the minimum carbon economic index value of 1.0 (refer to Equation (7)) was applied. When the ROI was $4 \%$ or higher and lower than $8 \%$, the carbon economic index was calculated via interpolation (refer to Equation (8)). When the ROI was $8 \%$ or higher, the maximum carbon economic index value was 1.2 (refer to Equation (9)).

$$
\begin{gathered}
\mathrm{E}=1.0(\text { if } \mathrm{CE}<4 \%) \\
\mathrm{E}=0.05 \times \mathrm{CE}+0.8(\text { if } 4 \% \leq \mathrm{CE}<8 \%) \\
\mathrm{E}=1.2(\text { if } 8 \% \leq \mathrm{CE})
\end{gathered}
$$

where $\mathrm{E}$ is the carbon economic index and $\mathrm{CE}$ is carbon economic efficiency.

\subsection{Calculation of GBI}

The GBI can be calculated as a relative efficiency ratio method using Equation (1) after calculating the carbon emission index, building habitability index, and carbon economic index. The carbon emission index is obtained by quantitatively deriving the construction and operational carbon emissions of an evaluated building (proposed construction project) and reference buildings, and the weighted relative values from each of these two sources are added to express the index. The building habitability index evaluates every assessment sub-criterion for an evaluated building and then uses simple summation, resulting in a weighted index. The carbon economic index evaluates life cycle costs related to carbon emissions and then divides the carbon reduction benefits by the carbon reduction costs (i.e., this is an evaluation of increasing construction costs to reduce carbon emissions). To establish the index range, a typical building was assumed to have a GBI ranging 1.2-5.0. The green building ratings according to the range of the GBI are suggested in Table 3 after referring to the G-SEED rating system used in South Korea [27].

Table 3. Ranges in the GBI.

\begin{tabular}{cc}
\hline Grade & GBI Range \\
\hline Excellent (Green 1st) & $4.0 \leq \mathrm{GBI}$ \\
Very Good (Green 2nd) & $3.0 \leq \mathrm{GBI}<4.0$ \\
Good (Green 3rd) & $2.5 \leq \mathrm{GBI}<3.0$ \\
General (Green 4th) & $2.0 \leq \mathrm{GBI}<2.5$ \\
Out of Grade & $\mathrm{GBI}<2.0$ \\
\hline
\end{tabular}

The GBI assessment results are presented as a graph in Figure 4. The two-dimensional graph comprises an $X$-axis and a $Y$-axis, representing building life cycle carbon emissions per unit area and GBI, respectively. It can effectively indicate methods for improving green building ratings through GBI, namely: (1) educing building life cycle carbon emissions per unit area of the $X$-axis for the same building habitability index and carbon economic index; (2) attaining an additional building habitability index for the same building life cycle carbon emissions and carbon economic index; (3) acquiring a carbon economic index for the same building habitability index and carbon emissions; and (4) improving the GBI with composite actions related to building life cycle carbon emissions, building habitability index, and carbon economic index. Moreover, if the building's sustainability is further improved in the future, the ranges for GBI 3.0 (grade 2) or higher could be subdivided and assigned 
with grades, and the weight for each index could be adjusted so it can be used as a green building certification system that is in agreement with national policies.

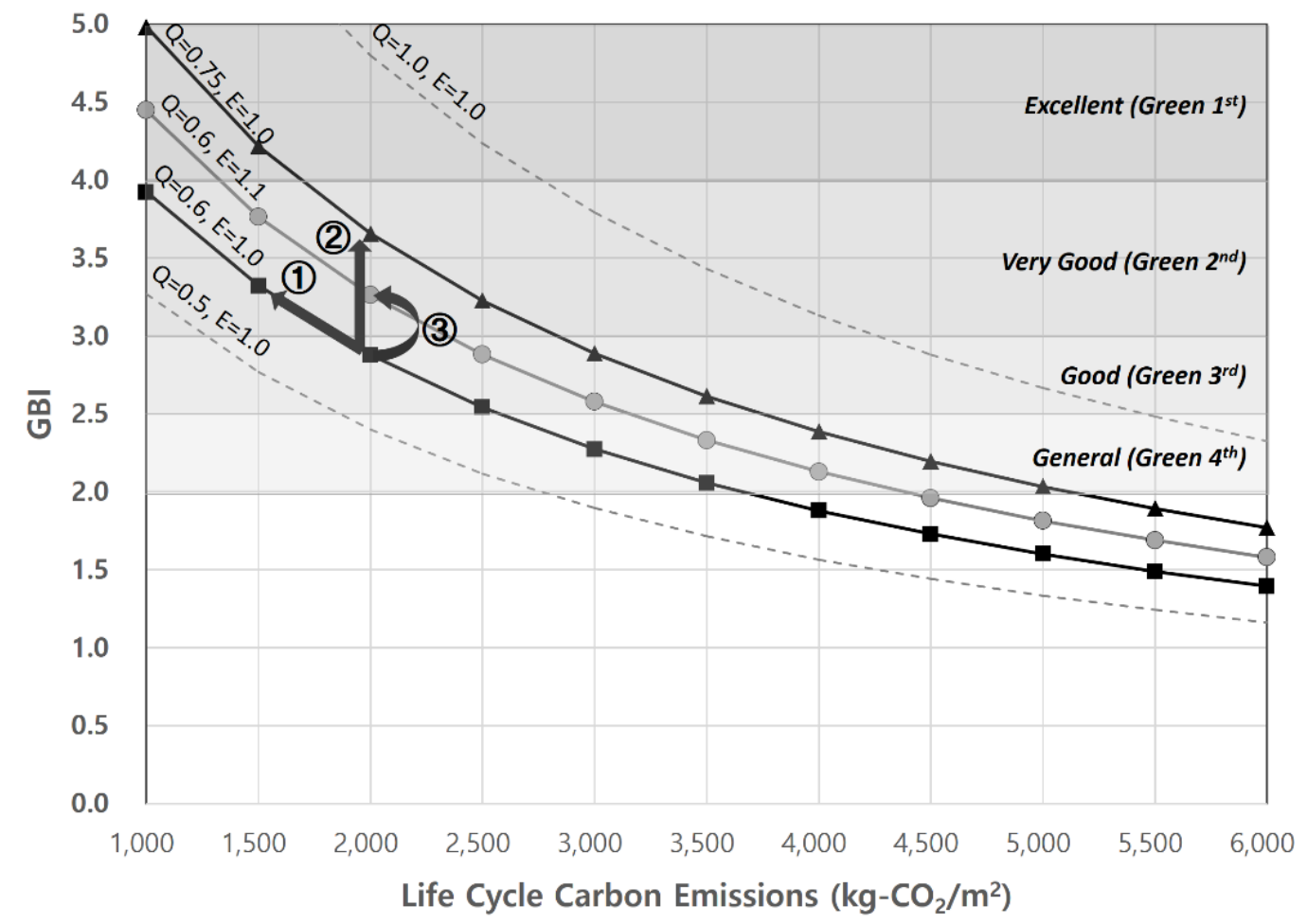

Figure 4. Framework of GBI assessment results.

\section{Case Study}

GBI was calculated for an Apartment Building A constructed in Seoul, South Korea, in order to investigate the applicability of the GBI Certification System suggested in this study. Then, the results were compared with previous G-SEED assessment findings for the same building. The apartment building was a reinforced concrete structure with 16 stories above ground level and 2 stories below ground level. It was rated with a score of 72.2 , which translated to a very good rating (green grade 2 ), with the conventional G-SEED certification. This apartment building was planned with the goal of reducing operational energy use by $50 \%$ compared to older buildings constructed in Korea, and it received a grade of 1 in the preliminary certification for building energy efficiency rating. Tables 4 and 5 show a summary for Apartment Building A and its previous G-SEED assessment results.

Table 4. Summary for Apartment Building A.

\begin{tabular}{cc}
\hline Title of the Business & Apartment Building A \\
\hline Purpose & Apartment building \\
Structure & RC structure column type \\
Gross floor area & $208,393 \mathrm{~m}^{2}$ \\
Exclusive area & $95,002 \mathrm{~m}^{2}$ \\
Service life & 40 years \\
\hline
\end{tabular}


Table 5. Previous G-SEED assessment results for Apartment Building A.

\begin{tabular}{cccc}
\hline Classification & Allotted Score & Obtained Score & Result \\
\hline Land Use & 4 & 0.00 & \\
Transportation & 4 & 3.60 & \\
Energy & 15 & 13.80 & G-SEED \\
Material and Resource & 24 & 6.60 & Score of 72.2 \\
Water & 13 & 8.80 & (Very Good/Green 2nd) \\
Air Pollution & 6 & 4.00 & \\
Maintenance & 4 & 4.00 & \\
Ecology & 12 & 7.00 & \\
Indoor Environment & 20 & 12.83 & \\
\hline
\end{tabular}

\subsection{Evaluation of Carbon Emission Index}

Carbon emissions associated with building construction and the operational carbon emission assessment of Apartment Building A and reference buildings must be conducted to calculate the carbon emission index (refer to Equation (2)). Accordingly, this study analyzed the amounts of the six main construction materials that were used, based on actual design statements for Apartment Building $\mathrm{A}$, and carbon emissions per unit area of the apartments were evaluated according to the building life cycle scenario of each main construction material discussed in Section 2.1. Moreover, operational carbon emissions were evaluated for a building service life of 40 years using the assessment results of annual carbon emissions per unit area from the preliminary certification of the building energy efficiency rating for the Apartment Building A. For comparison, carbon emissions associated with the construction of reference buildings were obtained by calculating the average carbon emissions per unit area for 32 apartment buildings previously constructed in South Korea using their respective design statements. Operational carbon emission estimates were obtained using the annual standard carbon emissions per unit area of an apartment building suggested by the certification criteria of South Korea's building energy efficiency rating system [60] to calculate carbon emissions during the building's service life of 40 years. In this manner, the building life cycle carbon emissions of Apartment Building A and reference apartment buildings were calculated as shown in Table 6. The carbon emission index (C) for Apartment Building A was calculated to be 0.19, as shown in Equation (10).

$$
\mathrm{C}=0.125 \times \frac{462.7}{496.5}+0.125 \times \frac{1,280.0}{2,252.6} \approx 0.19
$$

Table 6. Building life cycle carbon emissions of Apartment Building A and reference apartment buildings.

\begin{tabular}{cccc}
\hline \multirow{2}{*}{ Classification } & \multicolumn{2}{c}{ Carbon Emissions per Unit Area $\left(\mathbf{k g}-\mathrm{CO}_{\mathbf{2}} / \mathbf{m}^{\mathbf{2}} \mathbf{)}\right.$} \\
\cline { 2 - 4 } & & Apartment Building A & Reference Building \\
\hline \multirow{3}{*}{ Construction Stage } & Production Process & 412.3 & 445.0 \\
& Transportation Process & 17.9 & 18.3 \\
& Construction Process & 5.4 & 5.6 \\
\hline \multirow{2}{*}{ Operation Stage } & Operation Process & 1280.0 & 2252.6 \\
& Maintenance Process & 0.04 & 0.05 \\
\hline \multirow{2}{*}{ End-of-life Stage } & Dissolution Process & 20.3 & 20.7 \\
& Transportation Process & 6.1 & 6.1 \\
& Incineration Process & 0.3 & 0.3 \\
& Landfill Process & 0.4 & 0.4 \\
\hline Embodied Carbon Emissions & 462.7 & 496.5 \\
Operational Carbon Emissions & 1280.0 & 2252.6 \\
& Total & 1742.7 & 2749.1 \\
\hline
\end{tabular}




\subsection{Evaluation of Building Habitability Index}

A total of 49 assessment sub-criteria pertaining to specific areas, namely, ecology, health, function, energy efficiency, and resource efficiency, were assessed to calculate the building's habitability index. Thus, this study evaluated the assessment sub-criteria of each specific area based on previous G-SEED assessment results and construction drawings for Apartment Building A. There was a degree of overlap with the sub-criteria of the conventional G-SEED analysis. In this case, scores given to Apartment Building A by the conventional G-SEED method were assigned for the corresponding assessment sub-criteria, and scores for newly added assessment sub-criteria were determined using construction drawings and recorded data for Apartment Building A according to the certification criteria for each particular sub-criterion. This approach resulted in a total score of 68.25 for Apartment Building A, where weights were considered according to each specific area (refer to Table 7), and the building habitability index (Q) of this apartment building was calculated to be 0.68 , as shown in Equation (11).

$$
\mathrm{Q}=68.25 \times \frac{1}{100} \approx 0.68
$$

Table 7. Evaluation results of the building habitability index for Apartment Building A.

\begin{tabular}{cccccc}
\hline Classification & Weight Factor (A) & Allotted Score (B) & Obtained Score (C) & $\begin{array}{c}\text { Obtained Score Rates } \\
\text { (D = C/B) }\end{array}$ & $\begin{array}{c}\text { Final Obtained Score } \\
\text { (E = DXA) }\end{array}$ \\
\hline Ecology & 23 & 20 & 13.50 & 0.68 & 15.53 \\
Health & 22 & 36 & 22.00 & 0.61 & 13.44 \\
Function & 12 & 22 & 14.00 & 0.64 & 7.64 \\
Energy & 25 & 24 & 19.00 & 0.79 & 19.79 \\
Efficiency & & & & 0.66 & \\
Resource & 18 & 35 & 23.05 & 0.67 & 11.85 \\
Efficiency & 100 & 137 & 91.55 & 68.25 \\
Total & 12 & & & \\
\hline
\end{tabular}

\subsection{Evaluation of Carbon Economic Index}

To calculate the carbon economic index based on economic efficiency for Apartment Building A, construction costs for insulation, windows and doors, glass, and machine equipment, operational costs, and carbon trading profit were calculated first (refer to Equation (6)). This study confirmed the total construction cost per unit area for insulation, windows and doors, glass, and machine equipment to be $353.2 \mathrm{USD} / \mathrm{m}^{2}$ (1 United States dollar (USD) $=1080$ Korean Won) using design statements for Apartment Building A. The annual energy cost per unit area in the operational stage was estimated to be $5.6 \mathrm{USD} / \mathrm{m}^{2}$.year using the preliminary certification for the building energy efficiency rating obtained by Apartment Building A. In addition, working budgets for 30 apartment buildings previously constructed in Korea were analyzed to calculate the construction costs for insulation, windows and doors, glass, and machine equipment for the reference buildings. The percentage of construction cost for insulation, windows and doors, glass, and machine equipment compared to the construction cost for the entire building was derived and then calculated with standard construction costs obtained from the Korean Ministry of Transportation. A value of $258.7 \mathrm{USD} / \mathrm{m}^{2}$ was obtained. The Korean Apartment Building Management Information System [61] was used to select $11.1 \mathrm{USD} / \mathrm{m}^{2}$.year as the operational cost for the reference buildings, which was the average annual energy cost per unit area in the last five years from apartment buildings located in the same administrative district as Apartment Building A. Meanwhile, carbon emission trading profits were calculated based on annual operational carbon emissions of Apartment Building A and the reference buildings. For carbon emission trading, a price of 19.7 USD/ton, the average trading price in 2017 based on Korean exchange rates [62], was applied. As a result, construction cost, operational cost, and carbon emission trading profit were calculated for Apartment Building A and the reference buildings, as shown in Table 8. The carbon economic efficiency of Apartment Building A was calculated at 6.35\%, as shown in Equation (12), and the carbon economic index (E) was calculated to be 1.12, as shown in Equation (13). 


$$
\begin{gathered}
\mathrm{CE}=\left(\frac{11.1-5.6+0.5}{353.2-258.7}\right) \times 100 \approx 6.35 \\
\mathrm{E}=0.05 \times 6.35+0.8 \approx 1.12
\end{gathered}
$$

Table 8. Evaluation results of the carbon economic index.

\begin{tabular}{cccc}
\hline \multirow{2}{*}{ Classification } & \multicolumn{2}{c}{ Cost Per Unit Area (USD/m ${ }^{\mathbf{2}}$ ) } \\
\cline { 3 - 4 } & Insulation & Apartment Building A & Reference Building \\
\hline \multirow{3}{*}{ Construction Costs } & Window Frame & 49.4 & 11.4 \\
& Glass & 26.7 & 68.2 \\
& Machine Equipment & 260.7 & 8.8 \\
& Total & 353.2 & 170.3 \\
\hline Annual Operational Costs & 5.6 & 258.7 \\
\hline Annual Carbon Emission Trading Profit & 0.5 & 11.1 \\
\hline
\end{tabular}

\subsection{Evaluation of GBI}

Figure 5 shows the GBI assessment results for Apartment Building A. This value was calculated as 4.0, as shown in Equation (14), according to the previously evaluated carbon emission index, building habitability index, and carbon economic index. The certification rating was the highest at green grade 1 , as shown in Table 3.

$$
\mathrm{GBI}=\frac{0.68}{0.19} \times 1.12 \approx 4.0
$$

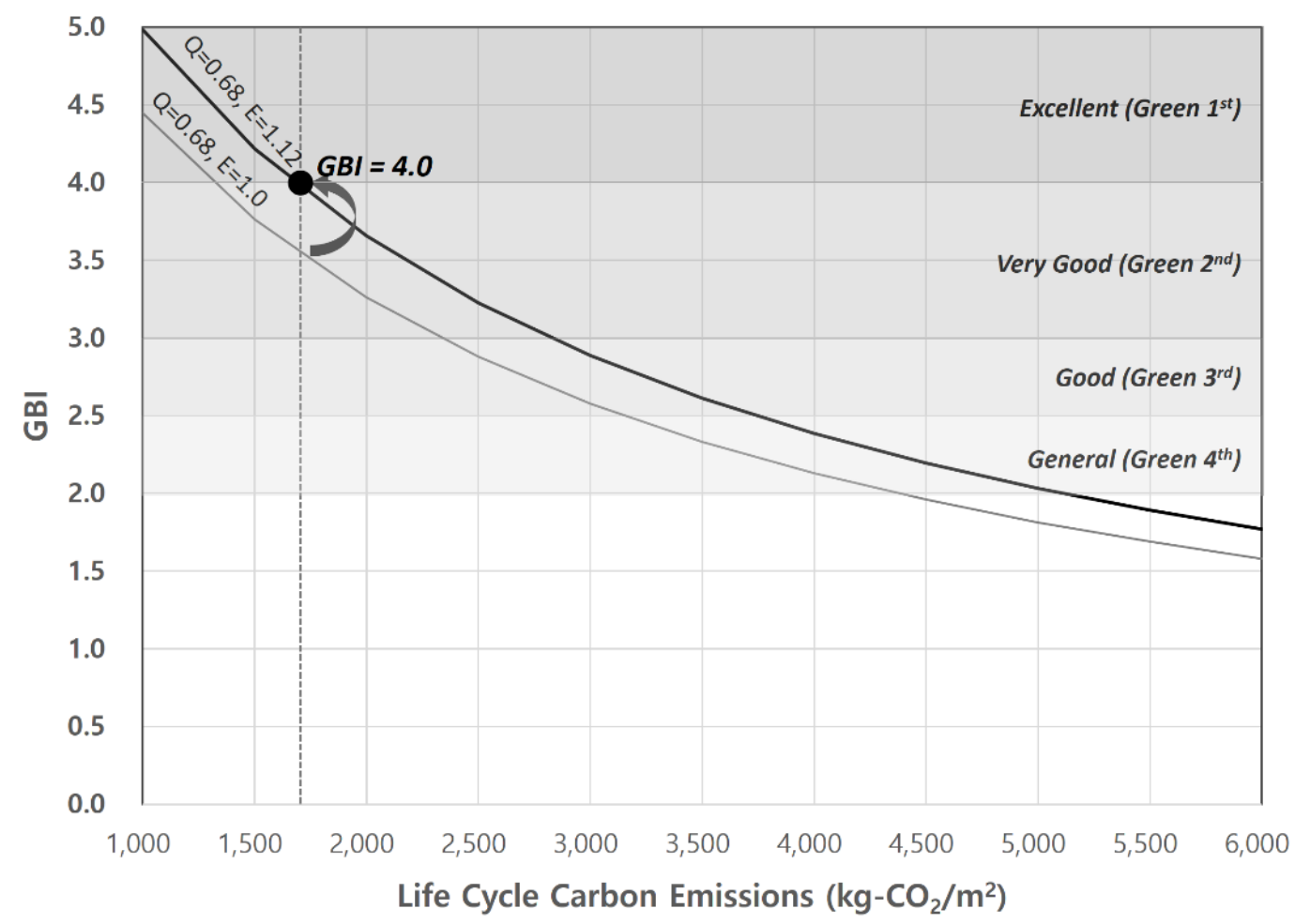

Figure 5. GBI assessment results. 


\subsection{Comprehensive Analysis}

As discussed in Section 3.4, Apartment Building A had a GBI of 4.0 and the highest green grade certification rating of 1 . This was a grade higher than the Green 2 nd rating obtained by Apartment Building A using the conventional G-SEED scoring methodology. The results for each assessment area were as follows:

The carbon emission index of Apartment Building A was 0.19 (refer to Equation (10)). The carbon emissions associated with the construction of Apartment Building A were $93.2 \%$ of that of the reference buildings. This was due to the use of higher strength concrete (27 MPa, $30 \mathrm{MPa})$ for vertical members than the $24 \mathrm{MPa}$ concrete that was conventionally used in the referenced buildings. This reduced the total area of concrete members, and, ultimately, the quantity of concrete. Meanwhile, the operational carbon emissions of Apartment Building A were estimated to be $56.8 \%$ of the reference buildings'. This was due to the high-performance insulation as well as glass and machine equipment that were used to achieve an operational energy reduction goal of $50 \%$ for Apartment Building A.

The building habitability index of Apartment Building A was estimated to be 0.68 (refer to Equation (11)). Specifically, the total score from the building habitability assessment result was 68.25 out of 100 , which was $94.5 \%$ of, and very close to, the score of 72.2 obtained from the conventional G-SEED. This was attributed to the assessment sub-criteria of building habitability and the score distribution having similar structures with the assessment sub-criteria of the conventional G-SEED. The carbon economic index of Apartment Building A was 1.12 (refer to Equation (13)). Specifically, the carbon economic efficiency was $6.35 \%$, which showed that the early construction cost for Apartment Building A was appropriately invested in an item that achieved efficient reduction in operational energy costs. Moreover, Apartment Building A had an excellent (Green 2nd) grade, with a GBI of 3.58 $(=0.68 / 0.19)$, before the carbon economic index was implemented as a weight. However, applying green technologies that offer significant operational cost reduction compared to early construction costs allowed an increase in the GBI rating by one grade.

The applicability of the GBI Certification System, which combines the carbon emission index, building habitability index, and carbon economic index, and considers the investment and profit associated with green technology implementation, was confirmed through the above analyses. Thus, the GBI Certification System suggested in this study calculated a green building certification rating based on building life cycle carbon emissions and carbon economic efficiency.

\section{Discussion}

The construction industry is currently seeking to strengthen the green building certification criteria, using the LCA system as part of an overall strategy for encouraging carbon emission reduction in building construction. However, for a green building certification system to effectively contribute to a reduction in carbon emissions, the LCA certification criteria must transition to a mandatory framework, and life cycle carbon emissions of a proposed building project should be compared with those of a reference building. Additional costs associated with its green construction must be a major element in any LCA criteria.

The GBI Certification System suggested in this study calculates the green building certification rating based on life cycle carbon emissions and carbon economic efficiency. Therefore, this system is more quantitative than G-SEED, promotes voluntary carbon emission reduction by evaluating cost effectiveness, and will ultimately contribute to the reduction of carbon emissions in new building constructions in South Korea. This is especially valuable where building technologies are implemented with extremely low operational energy consumption, such as zero-energy buildings slated for introduction in 2020 [63-67]. Using a life cycle carbon emission approach, a comprehensive evaluation of carbon emissions over the useful life of a building can be undertaken, and impacts associated with material production, building construction operation, and decommissioning, can be included. The proposed approach is far more accurate than an assessment system that focuses primarily on energy consumption reduction. Moreover, a GBI certification system is a practical approach for assessing 
public projects that incorporate operational energy reduction, overall carbon emission reduction, and economic efficiency evaluation into an effective tool for certifying green buildings.

The additional time, cost, and manpower associated with the GBI Certification System will be extremely limited compared with G-SEED because the GBI Certification System was designed to require only building LCA criteria and life cycle costing criteria as additional mandatory criteria. This feature is likely to boost the acceptance of the GBI Certification System in green building practice.

A GBI would not only serve as an integrated index for green building assessment but would also express individual building performance using a combination of three indices based on a TBL approach, namely, building habitability, carbon emission, and carbon economic efficiency. Thus, it can be used selectively, depending on the various needs of project developers and owners.

However, the GBI Certification System has a limitation in that the detailed weighting and grading of each item, certification level, and method of selecting a reference building are not clearly defined. Therefore, to improve practical use of the GBI Certification System, it is important to undertake various case studies that reflect the usage and characteristics of buildings, and consider more accurate weight setting, linkage with existing certification systems, and application of incentives.

\section{Conclusions}

The purpose of this study was to develop and propose a framework for a GBI Certification System that effectively reduces carbon emissions associated with building construction in South Korea. This proposed approach includes the following key aspects:

1. An overall efficiency index based on TBL sustainability analysis was developed. It combined a carbon emission index, building habitability index, and carbon economic index, thereby incorporating the environmental, social, and economic elements of the TBL concept. This framework was then combined with the concept of eco-efficiency and developed into a GBI Certification System, which calculates a green building certification rating based on life cycle carbon emissions and carbon economic efficiency. Therefore, this system is more quantitative than G-SEED, promotes voluntary carbon emission reduction by evaluating cost effectiveness, and will ultimately contribute to the reduction of carbon emissions in new building constructions in South Korea.

2. The relative efficiency ratio between the evaluated building (proposed project) and reference buildings in terms of carbon emissions attributed to the manufacturing phase of the materials required for building construction, actual construction, and operational carbon emissions (which comprise the building's life cycle carbon emissions) provides the foundation for the calculation of the carbon emission index. An assessment method was derived for this index and successfully applied to a case study.

3. Specific areas that represent building habitability were distinguished in terms of ecology, health, function, energy efficiency, and resource efficiency, and 49 assessment sub-criteria were selected to calculate the building habitability index. An assessment method was derived for this index and successfully applied to a case study.

4. The ratio of building construction costs associated with incorporated technologies that reduce life cycle carbon emissions to the carbon reduction benefits associated with the incorporated technologies realized over the building service life and carbon emission trading were calculated to arrive at the carbon economic index. An assessment method was derived for this index and successfully applied to a case study.

5. Case study analyses were employed to confirm the applicability of the GBI Certification System described in item 1. However, the GBI Certification System suffers from a limitation; the detailed weighting and grading of each item, certification level, and method of selecting a reference building are not clearly defined. Therefore, more practically oriented research, in the form of case 
studies reflecting the usage and characteristics of buildings, weight setting, linkage with existing certification systems, and application of incentives, should be carried out.

Author Contributions: All authors contributed substantially to all aspects of this article.

Acknowledgments: This research was supported by a grant (17CTAP-C114806-02) from the Technology Advancement Research Program (TARP), funded by the Ministry of Land, Infrastructure, and Transport of the Korean government.

Conflicts of Interest: The authors have no conflict of interest to declare.

\section{References}

1. Heinonen, J.; Säynäjoki, A.; Junnonen, J.; Pöyry, A.; Junnila, S. Pre-use phase LCA of a multi-story residential building: Can greenhouse gas emissions be used as a more general environmental performance indicator? Build. Environ. 2016, 95, 116-125. [CrossRef]

2. Lin, B.; Liu, H. $\mathrm{CO}_{2}$ mitigation potential in China's building construction industry: A comparison of energy performance. Build. Environ. 2015, 94, 239-251. [CrossRef]

3. Simpson, N.P.; Basta, C. Sufficiently capable for effective participation in environmental impact assessment? Environ. Impact Assess. Rev. 2018, 70, 57-70. [CrossRef]

4. Gorobets, A. Eco-centric policy for sustainable development. J. Clean. Prod. 2014, 64, 654-655. [CrossRef]

5. Braganca, L.; Mateus, R.; Koukkari, H. Building Sustainability Assessment. Sustainability 2010, 2, $2010-2023$. [CrossRef]

6. International Energy Agency (IEA). Energy Technology Perspectives 2010; OECD/IEA: Paris, France, 2010.

7. Li, X.; Yang, F.; Zhu, Y.; Gao, Y. An assessment framework for analyzing the embodied carbon impacts of residential buildings in China. Energy Build. 2014, 85, 400-409. [CrossRef]

8. Castro Marins, K. Comparative assessment of sustainability strategies applied to urban neighbourhoods in Brazil, Germany and Sweden. Int. J. Sustain. Build. Technol. Urban Dev. 2017, 8, 195-207.

9. Vonka, M.; Hajek, P.; Lupisek, A. SBToolCZ: Sustainability rating system in the Czech Republic. Int. J. Sustain. Build. Technol. Urban Dev. 2013, 1, 46-52. [CrossRef]

10. Vrieze, R.; Moll, H. An analytical approach towards sustainability-centered guidelines for Dutch primary school building design. Int. J. Sustain. Build. Technol. Urban Dev. 2017, 8, 93-124.

11. Darko, A.; Chan, A.P.C. Critical analysis of green building research trend in construction journals. Habitat Int. 2016, 57, 53-63. [CrossRef]

12. Mateus, R.; Bragança, L. Sustainability assessment and rating of buildings: Developing the methodology SBTool $^{\mathrm{PT}}$-H. Build. Environ. 2011, 46, 1962-1971. [CrossRef]

13. Shad, R.; Khorrami, M.; Ghaemi, M. Developing an Iranian green building assessment tool using decision making methods and geographical information system: Case study in Mashhad city. Renew. Sustain. Energy Rev. 2017, 67, 324-340. [CrossRef]

14. Zhang, Y.; Wang, J.; Hu, F.; Wang, Y. Comparison of evaluation standards for green building in China, Britain, United States. Renew. Sustain. Energy Rev. 2017, 68, 262-271. [CrossRef]

15. Ramachanderan, S.S.; Venkiteswaran, V.K.; Chuen, Y.T. Carbon $\left(\mathrm{CO}_{2}\right)$ Footprint Reduction Analysis for Buildings through Green Rating Tools in Malaysia. Energy Procedia 2017, 105, 3648-3655. [CrossRef]

16. Roh, S.; Tae, S. Building Simplified Life Cycle $\mathrm{CO}_{2}$ Emissions Assessment Tool (B-SCAT) to Support Low-Carbon Building Design in South Korea. Sustainability 2016, 8, 567. [CrossRef]

17. Geng, S.; Wang, Y.; Zuo, J.; Zhou, Z.; Du, H.; Mao, G. Building life cycle assessment research: A review by bibliometric analysis. Renew. Sustain. Energy Rev. 2017, 76, 176-184. [CrossRef]

18. Roh, S.; Tae, S. An integrated assessment system for managing life cycle $\mathrm{CO}_{2}$ emissions of a building. Renew. Sustain. Energy Rev. 2017, 73, 265-275. [CrossRef]

19. Rashid, A.F.A.; Yusoff, S. A review of life cycle assessment method for building industry. Renew. Sustain. Energy Rev. 2015, 45, 244-248. [CrossRef]

20. Oliveira, Z.L.; David, V.L.; Serra, S.M.B.; Barreto, D. Decision making process assisted by life cycle assessment: Greenhouse gas emission. Int. J. Sustain. Build. Technol. Urban Dev. 2017, 8, 244-253.

21. Dekkiche, H.; Taileb, A. The Importance of Integrating LCA into the LEED Rating System. Procedia Eng. 2016, 145, 844-851. [CrossRef] 
22. Lee, N.; Tae, S.; Gong, Y.; Roh, S. Integrated building life-cycle assessment model to support South Korea's green building certification system (G-SEED). Renew. Sustain. Energy Rev. 2017, 76, 43-50. [CrossRef]

23. BREEAM. Assessor Guidance Note GN08; BREEAM: Watford, UK, 2013.

24. AIA. AIA Guide to Building Life Cycle Assessment in Practice; AIA: Washington, DC, USA, 2010.

25. USGBC. Guide to LEED Certification. Available online: http://www.usgbc.org/cert-guide (accessed on 29 March 2018).

26. BREEAM UK New Construction. Available online: https:/ / www.breeam.com (accessed on 31 March 2018).

27. G-SEED. Available online: http://gseed.greentogether.go.kr (accessed on 31 March 2018).

28. Wu, X.; Peng, B.; Lin, B. A dynamic life cycle carbon emission assessment on green and non-green buildings in China. Energy Build. 2017, 149, 272-281. [CrossRef]

29. Ng, S.T.; Chen, Y.; Wong, J. Variability of building environmental assessment tools on evaluating carbon emissions. Environ. Impact Assess. Rev. 2013, 38, 131-141. [CrossRef]

30. Hoff, J. Life cycle assessment and the LEED green building rating system. In Proceedings of the Roof Consultants Institute 23rd International Convention, Phoenix, AZ, USA, 28 February-4 March 2008.

31. Russell, M. Enhancing Building Rating Systems Based on Carbon Footprinting. Ph.D. Thesis, The University of Florida, Gainesville, FL, USA, 2011.

32. The World Commission on Environment and Development (WCED). Our Common Future: Report of the World Commission on Environment and Development. Available online: http:/ / www.un-documents.net/ our-common-future.pdf (accessed on 12 March 2018).

33. Skouloudis, A.; Evangelinos, K.; Kourmousis, F. Development of an Evaluation Methodology for Triple Bottom Line Reports Using International Standards on Reporting. Environ. Manag. 2009, 44, 298-311. [CrossRef] [PubMed]

34. Rogers, M.; Ryan, R. The Triple Bottom Line for Sustainable Community Development. Local Environ. 2001, 6, 279-289. [CrossRef]

35. Hacking, T.; Guthrie, P. A framework for clarifying the meaning of Triple Bottom-Line, Integrated, and Sustainability Assessment. Environ. Impact Assess. Rev. 2008, 28, 73-89. [CrossRef]

36. Bagheri, A.; Hjorth, P. Planning for Sustainable Development: a Paradigm Shift towards a Process-Based Approach. Sustain. Dev. 2007, 15, 83-96. [CrossRef]

37. WBCSD. Eco-Efficiency Creating more Value with Less Impact; WBCSD: Geneva, Switzerland, 2000.

38. Roh, S.; Tae, S.; Suk, S.J.; Ford, G.; Shin, S. Development of a building life cycle carbon emissions assessment program (BEGAS 2.0) for Korea's green building index certification system. Renew. Sustain. Energy Rev. 2016, 53, 954-965. [CrossRef]

39. Dong, L.; Wang, Y.; Li, H.X.; Jiang, B.; Al-Hussein, M. Carbon Reduction Measures-Based LCA of Prefabricated Temporary Housing with Renewable Energy Systems. Sustainability 2018, 10, 718. [CrossRef]

40. Iban-Mohammed, T.; Greenough, R.; Taylor, S.; Ozawa-Meida, L.; Acquaye, A. Operational vs. embodied emissions in buildings-A review of current trends. Energy Build. 2013, 66, 232-245. [CrossRef]

41. Basbagill, J.; Flager, F.; Lepech, M.; Fischer, M. Application of life-cycle assessment to early stage building design for reduced embodied environmental impacts. Build. Environ. 2013, 60, 81-92. [CrossRef]

42. Luo, Z.; Yang, L.; Liu, J. Embodied carbon emissions of office building: A case study of China's 78 office buildings. Build. Environ. 2016, 95, 365-371. [CrossRef]

43. Chastas, P.; Theodosiou, T.; Bikas, D.; Kontoleon, K. Embodied Energy and Nearly Zero Energy Buildings: A Review in Residential Buildings. Procedia Environ. Sci. 2017, 38, 554-561. [CrossRef]

44. Zeng, R.; Chini, A. A review of research on embodied energy of buildings using bibliometric analysis. Energy Build. 2017, 155, 172-184. [CrossRef]

45. Wen, T.J.; Siong, H.C.; Noor, Z.Z. Assessment of embodied energy and global warming potential of building construction using life cycle analysis approach: Case studies of residential buildings in Iskandar Malaysia. Energy Build. 2015, 93, 295-302. [CrossRef]

46. Dixit, M.K. Life cycle embodied energy analysis of residential buildings: A review of literature to investigate embodied energy parameters. Renew. Sustain. Energy Rev. 2017, 79, 390-413. [CrossRef]

47. Roh, S.; Tae, S.; Suk, S.J.; Ford, G. Evaluating the embodied environmental impacts of major building tasks and materials of apartment buildings in Korea. Renew. Sustain. Energy Rev. 2017, 73, 135-144. [CrossRef] 
48. Roh, S.; Tae, S.; Shin, S. Development of building materials embodied greenhouse gases assessment criteria and system (BEGAS) in the newly revised Korea Green Building Certification System (G-SEED). Renew. Sustain. Energy Rev. 2014, 35, 410-421. [CrossRef]

49. ISO 14040. Environmental Management-Life Cycle Assessment-Principles and Framework; ISO: Geneva, Switzerland, 2006.

50. Korea Institute of Civil Engineering and Building Technology (KICT). Standard Estimating System of the Construction Work; KICT: Goyang-si, Gyeonggi-do, Korea, 2017.

51. Korea Environmental Industry \& Technology Institute (KEITI). Korea Life Cycle Inventory Database. 2004. Available online: http:/ / www.edp.or.kr/lci/lci_db.asp (accessed on 12 March 2018).

52. Korea Housing Act. Korea Ministry of Land, Infrastructure and Transport. Available online: http:/ / elaw. klri.re.kr/kor_service/lawView.do?hseq=25579\&lang=ENG (accessed on 31 March 2018).

53. Korea Environmental Industry \& Technology Institute (KEITI). Waste Statistics; KEITI: Seoul, Korea, 2017.

54. Li, Y.; Yu, W.; Li, B.; Yao, R. A multidimensional model for green building assessment: A case study of a highest-rated project in Chongqing. Energy Build. 2016, 125, 231-243. [CrossRef]

55. Li, P.; Froese, T.M. A green home decision-making tool: Sustainability assessment for homeowners. Energy Build. 2017, 150, 421-431. [CrossRef]

56. Alyami, S.H.; Rezgui, Y.; Kwan, A. Developing sustainable building assessment scheme for Saudi Arabia: Delphi consultation approach. Renew. Sustain. Energy Rev. 2013, 27, 43-54. [CrossRef]

57. Jang, D.; Yang, Y. A Study on the Use of Tax Increment Financing for Activating Urban Renewal Projects. Urban Des. Inst. Korea 2005, 6, 37-56.

58. Yi, H.; Lee, S.; Kim, J. An ESCO Business Model Using CER for Buildings' Energy Retrofit. Sustainability 2017, 9, 591. [CrossRef]

59. Lee, S.; Lee, B.; Kim, J.; Kim, J. A Financing Model to Solve Financial Barriers for Implementing Green Building Projects. Sci. World J. 2013, 2013. [CrossRef] [PubMed]

60. Korea Energy Agency. Building Energy Efficiency Rating Certification System. Available online: http:/ / building.energy.or.kr/build/CS/CSOLPage.do?page=422 (accessed on 31 March 2018).

61. Management and Information System of Apartment Building. Available online: http://www.k-apt.go.kr (accessed on 31 March 2018).

62. Korea Exchange. Marketdata. Available online: http://marketdata.krx.co.kr/mdi\#document=070301 (accessed on 31 March 2018).

63. Zuo, J.; Zhao, Z.Y. Green building research-current status and future agenda: A review. Renew. Sustain. Energy Rev. 2014, 30, 271-281. [CrossRef]

64. Chae, S.; Kim, J.; Chae, H. Investigation of Institutional Improvement through Evaluation of Zero-Energy Buildings. Korea Soc. Energy 2016, 25, 83-94. [CrossRef]

65. Harkouss, F.; Fardoun, F.; Biwole, F.H. Multi-objective optimization methodology for net zero energy buildings. J. Build. Eng. 2018, 16, 57-71. [CrossRef]

66. Annunziata, E.; Frey, M.; Rizzi, F. Towards nearly zero-energy buildings: The state-of-art of national regulations in Europe. Energy 2013, 57, 125-133. [CrossRef]

67. Haase, M.; Andresen, I.; Gustavsen, A.; Dokka, T.H.; Hestnes, A.G. Zero Emission Building Concepts in Office Buildings in Norway. Int. J. Sustain. Build. Technol. Urban Dev. 2011, 2, 150-156. [CrossRef]

(C) 2018 by the authors. Licensee MDPI, Basel, Switzerland. This article is an open access article distributed under the terms and conditions of the Creative Commons Attribution (CC BY) license (http://creativecommons.org/licenses/by/4.0/). 